\title{
Effects of different heating conditions on protein composition in each muscle type of yellowtail (Seriola quinqueradiata)
}

\author{
Ayumi Furuta ${ }^{1,2}$, Yumi Hamakawa ${ }^{2}$, Chinami Ishibashi ${ }^{3}$, Ryota Mabuchi ${ }^{4}$, Shota Tanimoto ${ }^{3, *}$ \\ ${ }^{1}$ Faculty of Health and Nutrition, Yamagata Prefectural Yonezawa University of Nutrition Sciences, Yonezawa, Yamagata 992-0025, Japan \\ ${ }^{2}$ Graduate School of Comprehensive Scientific Research, Prefectural University of Hiroshima, Hiroshima 734-8558, Japan \\ ${ }^{3}$ Faculty of Human Culture and Science, Prefectural University of Hiroshima, Hiroshima 734-8558, Japan \\ ${ }^{4}$ Faculty of Bioresource Sciences, Prefectural University of Hiroshima, Shobara, Hiroshima 727-0023, Japan
}

\begin{abstract}
To clarify the factors influencing the physical properties of fish after heat treatments, we investigated changes in the properties of proteins in the dorsal ordinary and dark muscle of yellowtail (Seriola quinqueradiata) heated under different conditions commonly used for the purposes of food hygiene. High-temperature/short-time heating $\left(85^{\circ} \mathrm{C}\right.$ for $90 \mathrm{~s}$ and $75^{\circ} \mathrm{C}$ for $60 \mathrm{~s}$ ) affected the protein solubility more than low-temperature/long-time heating $\left(63^{\circ} \mathrm{C}\right.$ for $\left.30 \mathrm{~min}\right)$. Sodium dodecyl sulphate-polyacrylamide gel electrophoresis and differential scanning calorimetry showed that low-temperature/long-time heating reduced the degree of actin denaturation in fish compared with that by other heating conditions. In addition, collagen solubility was enhanced with low-temperature/long-time heating. Therefore, these results suggest that differences in the degree of actin and collagen denaturation are responsible for the enhanced meat tenderness and diminished meat shrinkage, resulting from low-temperature/ long-time heating.
\end{abstract}

Keywords: Actin, Collagen, Fish, Heat treatment, Protein denaturation

\section{Introduction}

Yellowtail (Seriola quinqueradiata) is one of the most popular and important aquaculture species in Japan. The fish muscles are composed of dorsal ordinary muscle (OM) and dark muscle (DM), with different characteristics with respect to their texture and taste. Furthermore, as OM and DM are generally consumed simultaneously, the properties of each muscle type can influence the fish quality.

To obtain high-quality food products, it is necessary to control, factors such as texture, flavor, taste, and colour (Ishiwatari et al., 2013a). In addition, sufficient heating of food is required to minimize the risk of food poisoning. Therefore, suitable heating is required to maintain safety and palatability.

Received: Oct 6, 2021 Accepted: Oct 30, 2021

${ }^{*}$ Corresponding author: Shota Tanimoto

Faculty of Human Culture and Science, Prefectural University of Hiroshima, Hiroshima 734-8558, Japan

Tel: +81-82-251-9792, Fax: +81-82-251-9792, E-mail: s-tanimoto@pu-hiroshima.ac.jp

This is an Open Access article distributed under the terms of the Creative Commons Attribution Non-Commercial License (http://creativecommons.org/licenses/by$\mathrm{nc} / 4.0 /$ ) which permits unrestricted non-commercial use, distribution, and reproduction in any medium, provided the original work is properly cited.

Copyright $\odot 2022$ The Korean Society of Fisheries and Aquatic Science 
During heating of fish and meat, both textural changes and muscle fibre shrinkage occur due to the heat denaturation of muscle proteins, such as myosin, actin, and collagen (Ishiwatari et al., 2013a; Wattanachant et al., 2005). These changes affect the taste, juiciness, and texture of fish and are consequently related to fish product quality.

Freeze-induced denaturation of fish muscle proteins changes their chemical and physical properties (Sotelo et al., 1995). On the other hand, freezing also minimizes the deterioration of fish quality during storage (Konno, 2017). Frozen-thawed fish are generally used in the seafood processing industry and for daily cooking. Thus, the effect of heat treatment on the quality of frozen-thawed fish needs to be studied.

Several studies have reported changes in the texture of fish that vary with heating temperature and time (Kanoh et al., 1988; Qixing et al., 2014), and even sous-vide cooking (Fagan \& Gormley, 2005; Llave et al., 2018). However, as there had been no reports on the effects of heating conditions designed to prevent food poisoning on the texture of fish, we analysed the texture of OM and DM in yellowtail heated under different heating conditions (Furuta et al., 2020). Our results suggested that heating conditions affect the hardness and sample thickness of the OM and DM and that, in particular, low-temperature/longtime pasteurization (LTLT) results in more tender fish with less shrinkage. However, the mechanism of these textural changes under different heating conditions is still unclear.

In order to clarify the mechanism of these textural changes under different heating conditions set to prevent food poisoning, we investigated the effect of heating conditions on both the solubility and protein composition in OM and DM of yellowtail. In addition, we used differential scanning calorimetry (DSC) to evaluate the thermal denaturation of fish proteins, and we determined the collagen solubility of OM and DM after heating.

\section{Materials and Methods}

\section{Sample preparation}

Sample was prepared and heat treatments were performed according to a previous study (Furuta et al., 2020). Cultured yellowtail (Seriola quinqueradiata) $(n=3)$ were purchased with an average weight of $3.2 \pm 0.5 \mathrm{~kg}$. Fish were then filleted and skinned, and the fillet was sliced to a $20 \mathrm{~mm}$ thickness $(94.4 \pm 9.8$ $\mathrm{mm}$ length $\times 34.3 \pm 4.4 \mathrm{~mm}$ width). Sliced samples were wrapped in a polyethylene film, frozen in a blast chiller/freezer (iRiNOXAL-5M, FMI, Osaka, Japan), and stored at $-80^{\circ} \mathrm{C}$ un- der atmospheric conditions until heat treatment. Before the heat treatment, the samples were thawed in an ice-water slurry for $1 \mathrm{~h}$ and stored at $4^{\circ} \mathrm{C}$. The samples were heated in a steam convection oven (ACO-060GS, AIHO, Aichi, Japan) in steam mode at $100 \%$ humidity. Each part of the yellowtail was heated under the following heating conditions: (1) heating until the internal core temperature of the sample reaches $85^{\circ} \mathrm{C}$ followed by maintaining the temperature for $90 \mathrm{~s}$ (to inactivate norovirus for bivalve molluscs (FAO \& WHO, 2012); $85^{\circ} \mathrm{C}$, high-temperature/ short-time heating [HTST]) (2) heating until the internal core temperature of the sample reaches $75^{\circ} \mathrm{C}$ followed by maintaining the temperature for $60 \mathrm{~s}$ (to kill foodborne pathogens, such as Escherichia coli $\mathrm{O} 157$ for meat [Bureau of Social Welfare and Public Health, Tokyo Metropolitan Government, 2021]; $75^{\circ} \mathrm{C}$, HTST) and (3) maintaining the chamber temperature at $63{ }^{\circ} \mathrm{C}$ for $30 \mathrm{~min}$ (for specific heated processed meat products [Ministry of Health and Welfare, Japan, 1948]; used for fish and fishery products [FDA, 2020] to ensure food safety against bacterial pathogens in seafood processing; $63{ }^{\circ} \mathrm{C}$, LTLT). Heated samples were incubated at $30^{\circ} \mathrm{C}$ for $2 \mathrm{~h}$ for texture analysis, and stored at the above-mentioned conditions until analysis. This procedure was conducted independently for each fish in this study $(n=3)$.

\section{Determination of protein composition}

Proteins in OM and DM were fractionated according to the method described by Qixing et al. (2014). Briefly, samples were homogenized with 10 volumes of solution A (15.6 mM Na $2 \mathrm{H}$ $\left.\mathrm{PO}_{4}, 3.5 \mathrm{mM} \mathrm{KH} \mathrm{PO}_{4}[\mathrm{pH} 7.5]\right)$ and centrifuged at $5,000 \times \mathrm{g}$ for $15 \mathrm{~min}$. The extraction process was repeated twice. The supernatants were combined and mixed with cold 50\% trichloroacetic acid (TCA) to a final TCA concentration of $10 \%$. The resulting precipitate was collected by centrifugation at $5,000 \times \mathrm{g}$ for $15 \mathrm{~min}$ (water-soluble fraction; WSF). The supernatant was used to determine the non-protein nitrogen fraction (NPNF). The pellet was homogenized with 10 volumes of solution $\mathrm{B}(0.45$ $\mathrm{M} \mathrm{KCl}, 15.6 \mathrm{mM} \mathrm{Na} \mathrm{HPO}_{4}, 3.5 \mathrm{mM} \mathrm{KH}_{2} \mathrm{PO}_{4}[\mathrm{pH}$ 7.5]) and centrifuged at $5,000 \times \mathrm{g}$ for $15 \mathrm{~min}$. The extraction process was repeated twice. The supernatants were combined to form the salt-soluble fraction (SSF). The precipitate was stirred with 10 volumes of $0.1 \mathrm{M} \mathrm{NaOH}$ for $2 \mathrm{~h}$. The mixture was centrifuged at 5,000 $\times \mathrm{g}$ for $15 \mathrm{~min}$ with the resulting supernatant becoming the alkali-soluble fraction (ASF), and the final residue was used to determine the alkali-insoluble fraction (AIF). The nitrogen content in each fraction was determined by the Dumas combustion method using a Vario Max CN nitrogen analyser (Ele- 
mentar Analysensysteme GmbH, Hanau, Germany). The data are presented as the protein composition ratio (\%), which is the ratio of nitrogen content of each fraction to the sum of nitrogen content of all fractions.

\section{Sodium dodecyl sulphate-polyacrylamide gel electrophore- sis (SDS-PAGE)}

SDS-PAGE was performed on 10\% gels (e-Pagel, Atto, Tokyo, Japan) according to the method described by Laemmli (1970). A total protein fraction (TF) was extracted according to a method described by Numakura et al. (1985) with slight modifications. After chopping, filet tissue samples were heated at $100^{\circ} \mathrm{C}$ for 10 min in solution C (8M urea, 2\% SDS, 2\% 2-mercaptoethanol, $20 \mathrm{mM}$ Tris- $\mathrm{HCl}$ buffer [pH 8.8]) and stirred for $20 \mathrm{~h}$. After centrifugation at $12,100 \times \mathrm{g}$ for $30 \mathrm{~min}$, supernatant samples containing $5.0 \mu \mathrm{g}$ protein were separated by electrophoresis. WSF and SSF samples were also separated by SDS-PAGE. SSF samples were mixed with cold 50\% TCA to a final TCA concentration of $10 \%$, and centrifuged at $10,000 \times \mathrm{g}$ for $5 \mathrm{~min}$. In addition to WSF, these pellets were washed with acetone to remove residual TCA and re-dissolved in solution D (8M urea, $4 \%$ SDS, 5\% 2-mercaptoethanol, $25 \mathrm{mM}$ Tris-HCl buffer [pH 6.8]). The supernatants were mixed with the same volume of SDS-PAGE sample buffer (4\% SDS, 10\% 2-mercaptoethanol, 20\% glycerol, $0.005 \%$ bromophenol blue in $0.125 \mathrm{M}$ Tris-HCl buffer [pH 6.8]) and heated at $95^{\circ} \mathrm{C}$ for $5 \mathrm{~min}$. The samples, each containing 5.0 $\mu \mathrm{g}$ protein, were loaded into each lane. After electrophoresis, the gels were stained with Coomassie Brilliant Blue.

\section{Differential scanning calorimetry (DSC)}

DSC analysis was performed using a DSC-60Plus thermal analyser (Shimadzu, Kyoto, Japan) with distilled water used as a reference. $\mathrm{N}_{2}$ at a flow rate of $30 \mathrm{~mL} / \mathrm{min}$ was used as carrier gas. Samples $(15.0 \mathrm{mg})$ were weighed and hermetically sealed into aluminium pans using a sealer. The samples were cooled with liquid nitrogen as a cooling medium and scanned from $20^{\circ} \mathrm{C}$ to $80^{\circ} \mathrm{C}$ at a rate of $5^{\circ} \mathrm{C} \mathrm{min}^{-1}$. The thermal analysis software TA60WS (Shimadzu) was used to analyse the experimental data. The maximum temperature at each peak was recorded as the maximum peak temperature $\left(T_{\max }\right)$. The denaturation enthalpy $(\Delta \mathrm{H})$ was estimated from the area bound by a thermogram and the baseline.

\section{Collagen content analysis}

Soluble collagen in the OM and DM was extracted according to the method of Qixing et al. (2014) with slight modifications. In short, samples were homogenized with four volumes of solution E (32.8 mM NaCl, $\left.1.5 \mathrm{mM} \mathrm{KCl,} 0.5 \mathrm{mM} \mathrm{CaCl}_{2}\right)$, heated for 15 $\mathrm{min}$ at $50^{\circ} \mathrm{C}$, and centrifuged for $30 \mathrm{~min}$ at $2,300 \times \mathrm{g}$. Pellets were resuspended in solution $\mathrm{E}$ and re-centrifuged. The supernatants were combined (soluble collagen fraction). $\mathrm{OM}$ and DM were used to determine the total collagen content (total collagen fraction). After $\mathrm{HCl}$ was added to a final concentration of $6 \mathrm{M}$, the samples were hydrolysed at $130^{\circ} \mathrm{C}$ for $3 \mathrm{~h}$. The filtered samples were then evaporated. Hydroxyproline content in the hydrolysed samples was analysed according to the method of Woessner (1961), and this number was converted to collagen content using a factor of 9.75 (Zenitani \& Yamakita, 1956). Collagen solubility, which is the ratio of soluble collagen amount to total collagen amount, was then calculated.

\section{Statistical analysis}

One-way factorial analysis of variance (ANOVA) and Tukey's multiple-range test were used to test the differences among mean values using SPSS Statistics 25 (IBM Japan, Tokyo, Japan). The significance level was set at $5 \%$.

\section{Results}

\section{Determination of protein composition}

Fig. 1 shows the changes in protein composition of OM and DM under different heating conditions, based on protein solubility. The NPNF levels of OM and DM were not significantly different among the samples. However, WSF levels and SSF levels in heated samples were significantly lower than those in unheated samples $(p<0.05)$. The ASF levels in heated samples were significantly higher and lower $(p<0.05)$ than those of unheated $\mathrm{OM}$ and DM, respectively, except for DM samples heated at $63^{\circ} \mathrm{C}$. The AIF levels in heated samples were significantly higher $(p<0.05)$ than those of unheated OM and DM. Among the heating treatments, the ASF and AIF levels in OM after heating at $63{ }^{\circ} \mathrm{C}$ were higher and lower than those after other heating conditions, respectively, although not significantly. The AIF levels of DM heated at 75 and $85^{\circ} \mathrm{C}$ were significantly higher $(p<0.05)$ than those heated at $63^{\circ} \mathrm{C}$.

\section{Sodium dodecyl sulphate-polyacrylamide gel electrophore- sis (SDS-PAGE)}

SDS-PAGE banding patterns in OM and DM fractions treated with different heating conditions are shown in Figs. 2 and 3. The 
(A) $\mathrm{OM}$

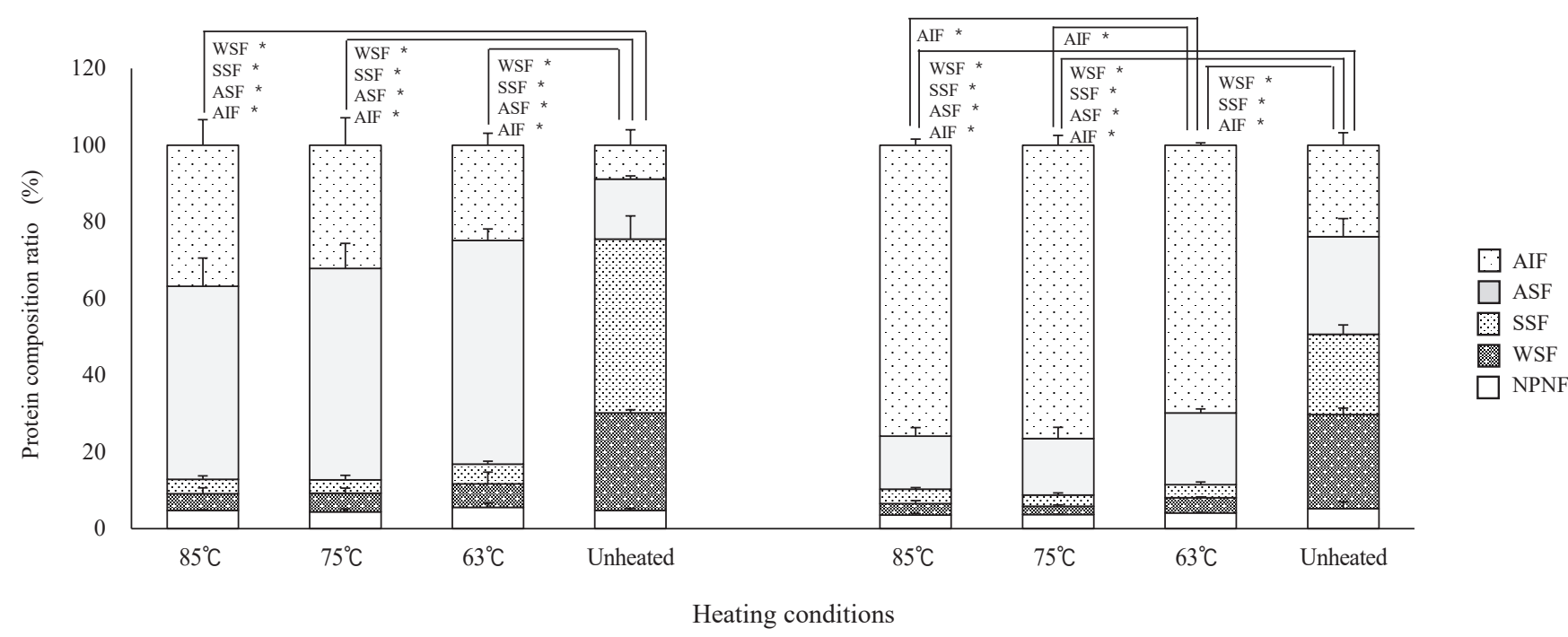

Fig. 1. Changes of protein composition of $\mathrm{OM}$ and $\mathrm{DM}$ after heating under different conditions. (A) Ordinary muscle, (B) Dark muscle. Protein composition ratio (\%): the nitrogen content of each fraction / the sum of nitrogen content of all fractions $\times 100$. Error bars represent SD for sample triplicates $(n=3) .{ }^{*}$ Asterisks indicate significant differences between samples $(p<0.05)$. AlF, alkaliinsoluble fraction; ASF, alkali-soluble fraction; SSF, salt-soluble fraction; WSF, water-soluble fraction; NPNF, non-protein nitrogen fraction.
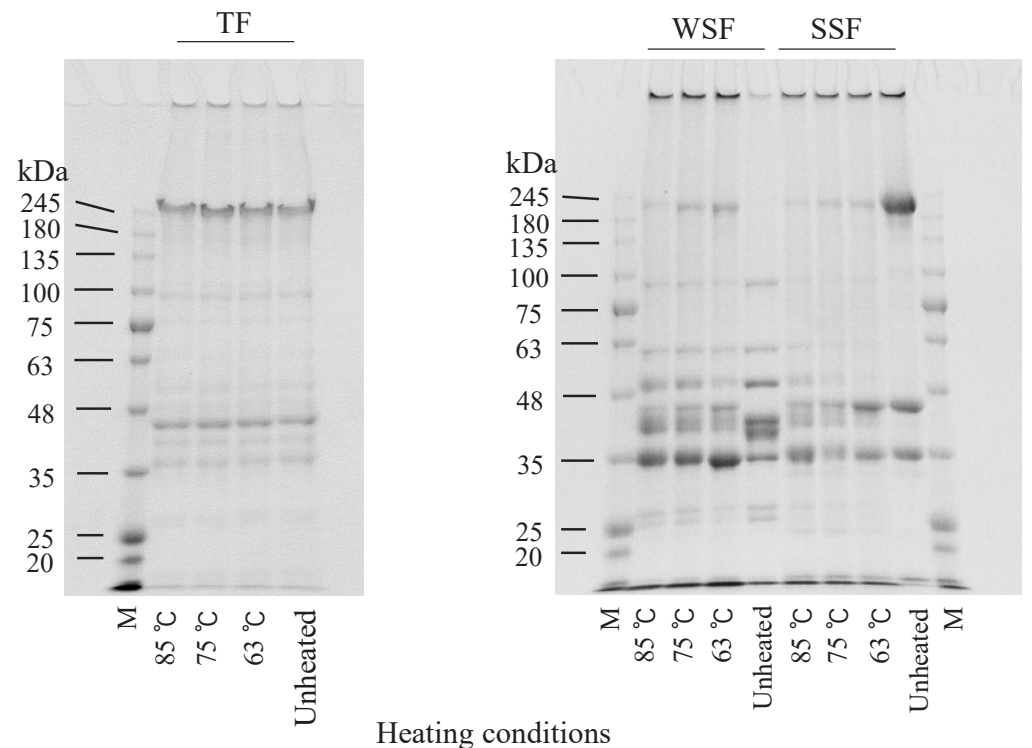

Fig. 2. SDS-PAGE patterns of each fraction in OM after heating under different conditions. TF, total protein fraction; WSF, watersoluble fraction; $\mathrm{SSF}$, salt-soluble fraction; $\mathrm{M}$, protein molecular weight marker; $\mathrm{OM}$, ordinary muscle.

TF protein profile was not changed remarkably by heating, indicating that heating under present conditions does not promote protein degradation. In contrast, WSF and SSF banding patterns in $\mathrm{OM}$ were noticeably altered by heating. The band intensities around $33 \mathrm{kDa}$ for the WSF, between 180 and $245 \mathrm{kDa}$, and also at approximately $48 \mathrm{kDa}$ for the SSF, visibly decreased after 

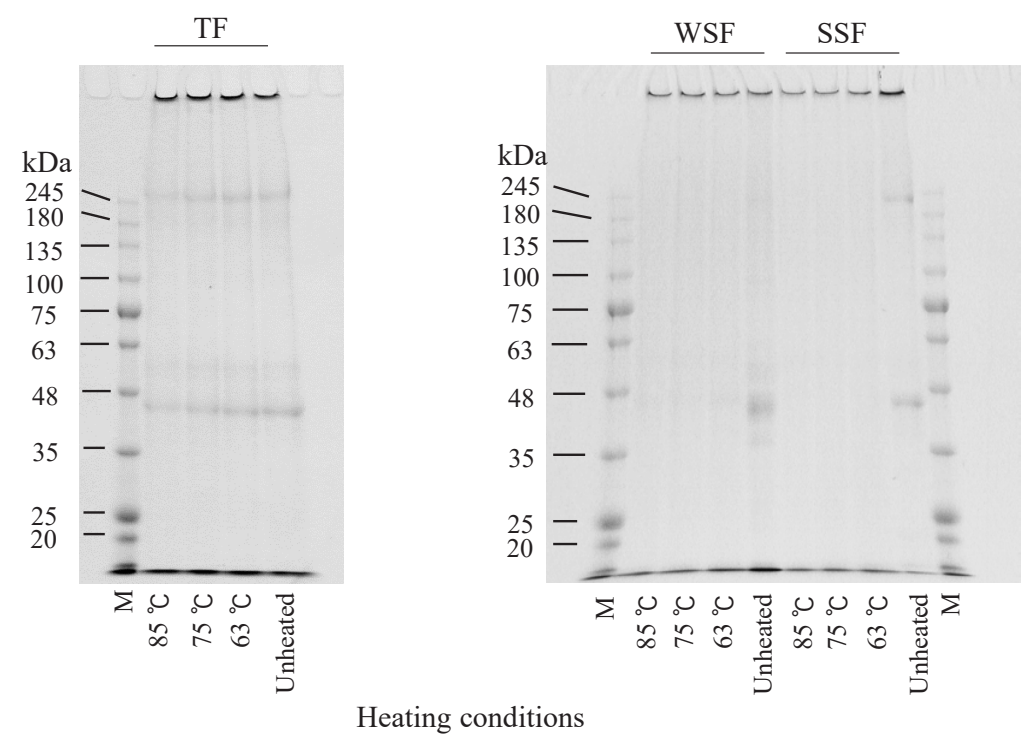

Fig. 3. SDS-PAGE patterns of each fraction in DM after heating under different conditions. TF, total protein fraction; WSF, watersoluble fraction; SSF, salt-soluble fraction; M, protein molecular weight marker; DM, dark muscle.

HTST treatment compared to LTLT. The former $(33 \mathrm{kDa})$ band was consistent with the expected size of tropomyosin (Daifuku et al., 2011), and the latter two bands (between 180 and $245 \mathrm{kDa}$ and approximately $48 \mathrm{kDa}$ ) were tentatively identified as myosin and actin, respectively, based on their size (Liang et al., 2012). For the WSF and SSF of DM, the band intensities of proteins were lower in unheated DM than in unheated OM. In addition, the protein bands of both fractions disappeared after heating.

\section{Differential scanning calorimetry (DSC)}

DSC thermograms of OM and DM after heating under different conditions are shown in Fig. 4. Two main peaks, the first peak (peak 1) and third peak (peak 3) observed for the unheated samples mainly corresponded to the denaturation of myosin and other components, and actin, respectively (Akahane et al., 1985). The smaller peak (the second peak; peak 2) was probably related to sarcoplasmic proteins (Hastings et al., 1985). The values of $T_{\max }$ and $\Delta \mathrm{H}$ are listed in Table 1. The $T_{\max }$ of unheated samples was observed at $45.8^{\circ} \mathrm{C}$ for peak $1,60.7^{\circ} \mathrm{C}$ for peak 2 , and $71.6^{\circ} \mathrm{C}$ for peak 3 in $\mathrm{OM}$, and at $49.5^{\circ} \mathrm{C}, 60.1^{\circ} \mathrm{C}$, and $71.0^{\circ} \mathrm{C}$ in DM, respectively. These peaks were not observed in the samples heated at $85^{\circ} \mathrm{C}$ and $75^{\circ} \mathrm{C}$. However, extremely small peaks (peak 3) for OM and DM heated at $63^{\circ} \mathrm{C}$ were detected at $T_{\max }$ values of $74.5^{\circ} \mathrm{C}$ and $72.7^{\circ} \mathrm{C}$, respectively.

\section{Collagen content}

Table 2 shows the collagen content of OM and DM after heating under different conditions. No significant differences in the soluble collagen levels in all OM samples were observed; however, among the heated samples, the collagen from the sample heated at $63^{\circ} \mathrm{C}$ showed a more increase in solubility compared to the unheated sample. DM showed no significant changes in collagen after heating; however, among the heated samples, the soluble collagen content and collagen solubility of DM heated at $63^{\circ} \mathrm{C}$ were more increased than those of unheated DM.

\section{Discussion}

Among native proteins in fish, sarcoplasmic proteins such as myoglobin are present in the WSF. In contrast, myofibrillar proteins, consisting mainly of myosin and actin, are included in the SSF. Most of these proteins are rapidly denatured during heat treatment, leading to changes in overall protein solubility. Following such heat treatments, these denatured proteins migrate into the ASF or AIF. During heating, the shrinkage of myofibrillar proteins and collagen, which denature and coagulate, cause an increase in the hardness of the meat (Niamnuy et al., 2007). Increasing the heating temperature also accelerates overall protein denaturation in fish. Myofibrillar proteins are specific contributors to fish texture (Ovissipour et al., 2013) and consequently their heating and denaturation results in the meat 
(A) $\mathrm{OM}$

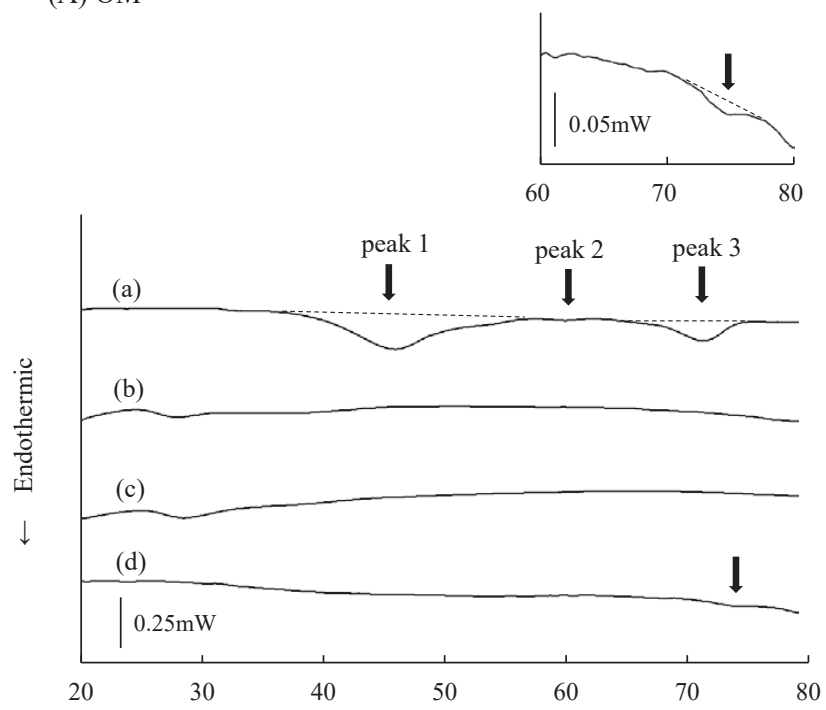

(B) DM
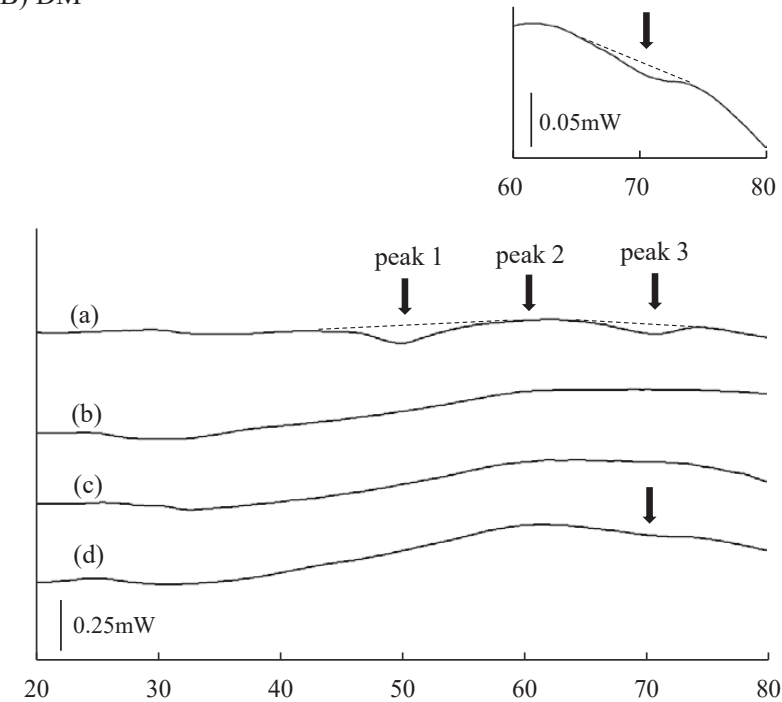

Temperature $\left({ }^{\circ} \mathrm{C}\right)$

Fig. 4. DSC thermograms of OM and DM after heating under different conditions. (A) Ordinary muscle, (B) Dark muscle. Heating conditions: (a) Unheated; (b) $85^{\circ} \mathrm{C}$; (c) $75^{\circ} \mathrm{C}$; (d) $63^{\circ} \mathrm{C}$. Insert presents the magnified thermogram of (d) from $60^{\circ} \mathrm{C}$ to $80^{\circ} \mathrm{C}$. DSC, differential scanning calorimetry.

Table 1. The maximum peak temperature $\left(T_{\max }\right)$ and the denaturation enthalpy change $(\Delta \mathrm{H})$ of $\mathrm{OM}$ and DM after heating under different conditions

\begin{tabular}{|c|c|c|c|c|c|c|c|c|}
\hline \multirow{2}{*}{$\begin{array}{l}\text { Muscle types } \\
\text { Heating conditions }\end{array}$} & \multicolumn{4}{|l|}{$\mathrm{OM}$} & \multicolumn{4}{|l|}{ DM } \\
\hline & $85^{\circ} \mathrm{C}$ & $75^{\circ} \mathrm{C}$ & $63^{\circ} \mathrm{C}$ & Unheated & $85^{\circ} \mathrm{C}$ & $75^{\circ} \mathrm{C}$ & $63^{\circ} \mathrm{C}$ & Unheated \\
\hline \multicolumn{9}{|l|}{$\operatorname{Tmax}\left({ }^{\circ} \mathrm{C}\right)$} \\
\hline Peak 1 & - & - & - & $45.8 \pm 0.4$ & - & - & - & $49.5 \pm 0.4$ \\
\hline Peak 2 & - & - & - & $60.7 \pm 0.3$ & - & - & - & $60.1 \pm 0.0$ \\
\hline Peak 3 & - & - & $74.5 \pm 0.3$ & $71.6 \pm 0.3$ & - & - & $72.7 \pm 0.5$ & $71.0 \pm 0.2$ \\
\hline \multicolumn{9}{|l|}{$\Delta \mathrm{H}(\mathrm{J} / \mathrm{g})$} \\
\hline Peak 1 & - & - & - & $1.37 \pm 0.22$ & - & - & - & $0.28 \pm 0.06$ \\
\hline Peak 2 & - & - & - & $0.02 \pm 0.01$ & - & - & - & $0.01 \pm 0.00$ \\
\hline Peak 3 & - & - & $0.02 \pm 0.01$ & $0.39 \pm 0.02$ & - & - & $0.05 \pm 0.02$ & $0.18 \pm 0.01$ \\
\hline
\end{tabular}

The values indicate means \pm SD of triplicate determinations $(n=3)$.

$\mathrm{OM}$, ordinary muscle; DM, dark muscle.

Table 2. Collagen contents of OM and DM after heating with yellowtail heated under different conditions

\begin{tabular}{|c|c|c|c|c|c|c|c|c|}
\hline Muscle types & $\mathrm{OM}$ & & & & $\mathrm{DM}$ & & & \\
\hline Heating conditions & $85^{\circ} \mathrm{C}$ & $75^{\circ} \mathrm{C}$ & $63^{\circ} \mathrm{C}$ & Unheated & $85^{\circ} \mathrm{C}$ & $75^{\circ} \mathrm{C}$ & $63^{\circ} \mathrm{C}$ & Unheated \\
\hline Soluble collagen (mg/fish meat g) & $1.56 \pm 0.55$ & $1.53 \pm 0.41$ & $2.18 \pm 0.24$ & $1.05 \pm 0.64$ & $1.24 \pm 0.23$ & $1.49 \pm 0.28$ & $1.65 \pm 0.19$ & $0.93 \pm 0.35$ \\
\hline Total collagen (mg/fish meat $\mathrm{g}$ ) & $4.52 \pm 0.51$ & $3.88 \pm 1.31$ & $4.00 \pm 0.39$ & $5.63 \pm 0.32$ & $4.22 \pm 0.67$ & $4.71 \pm 1.11$ & $4.61 \pm 1.32$ & $5.90 \pm 0.80$ \\
\hline Collagen solubility (\%) & $34.2 \pm 9.5^{\mathrm{ab}}$ & $40.0 \pm 2.6^{\mathrm{ab}}$ & $54.6 \pm 6.6^{\mathrm{a}}$ & $18.7 \pm 11.4^{b}$ & $30.3 \pm 9.9$ & $31.9 \pm 4.7$ & $37.7 \pm 10.7$ & $16.4 \pm 7.9$ \\
\hline
\end{tabular}

The values indicate means \pm SD of triplicate determinations $(n=3)$.

Collagen solubility (\%): soluble collagen amount / total collagen amount $\times 100$.

Different small letters indicate significant differences between treatments $(p<0.05)$.

$\mathrm{OM}$, ordinary muscle; DM, dark muscle. 
becoming tougher (Dunajski, 1980).

In this study, the ASF and AIF levels in the OM significantly increased after heating under different conditions, with LTLT showing higher ASF and lower AIF values than those under other heating conditions, although not significantly (Fig. 1). The levels of AIF in all heated DM samples were significantly higher than those in the unheated samples. However, among the heated samples, the levels in DM heated at LTLT were lower than those in other heated samples. Moreover, in contrast to the other samples, the heated samples in DM with LTLT did not show a significant decrease in the levels of ASF after heating. These results suggest that the degree of protein denaturation in DM after LTLT was lower than that of the other heating conditions, and this might have resulted in the more tender texture of the fish after LTLT treatment.

Following this analysis, SDS-PAGE was performed to evaluate the solubility changes of each protein due to denaturation and aggregation during the heating processes (Figs. 2 and 3). The band intensities of some proteins in WSF and SSF in OM heated at higher temperatures were lower than those that underwent LTLT treatment. This suggests that treatments at higher temperatures resulted in increased denaturation of these proteins more (Qixing et al., 2014) and simultaneously altered their solubility more. In particular, for the SSF in OM, the band at approximately $48 \mathrm{kDa}$, identified as actin, was more intense after LTLT than after HTST. These results indicate that the solubility change of actin in OM due to protein denaturation did not occur after heating with LTLT conditions when compared with that under other heating conditions. The band around $33 \mathrm{kDa}$ for the WSF in OM was consistent with tropomyosin which is a highly heat-stable protein (Woods, 1969). In fish muscle, actin is bound to thin filament proteins, such as troponin and tropomyosin (Godiksen et al., 2009). The band around $33 \mathrm{kDa}$, as well as the band around $48 \mathrm{kDa}$, decreased in intensity after HTST compared to LTLT (Fig. 2). Therefore, it appears that the solubility changes in tropomyosin, as well as actin, were a result of the different heating conditions. However, Samejima et al. (1982) concluded that tropomyosin does not influence the gel texture of meat. Thus, the structural change of tropomyosin due to heating of fish may not be related to the textural changes that we observed. On the other hand, the protein bands observed in the WSF and SSF of unheated DM samples disappeared after heating (Fig. 3); therefore, it was difficult to compare the protein compositions of DM after heating under different conditions.

During DSC analysis, slight peaks were observed in the
$\mathrm{OM}$ and $\mathrm{DM}$ samples at $63^{\circ} \mathrm{C}$, suggesting that actin was not partly denatured after heating (Fig. 4 and Table 1). Ishiwatari et al. (2013a) reported that the effect of myosin denaturation of meat on the elastic modulus is small, while that of actin denaturation has a remarkable impact. Namely, heating at a higher temperature than that required for thermal denaturation of actin causes the muscle fibres to contract, resulting in firmer meat (Tornberg, 2005). This means that the denaturation level of actin affects the whole structure of myofibrillar proteins; in other words, incomplete denaturation of actin leads to more tender heated meat (Ishiwatari et al., 2013b). Thus, the difference in the degree of actin denaturation may be one of the reasons why the meat heated with LTLT in this study was generally more tender and may also explain why muscle contraction of fish was suppressed in our previous study (Furuta et al., 2020).

In addition, collagen solubilization of $\mathrm{OM}$ and $\mathrm{DM}$ showed a tendency to increase with LTLT treatment (Table 2). Collagen fibres treated at temperatures above $60^{\circ} \mathrm{C}$ lose their native structure and begin to solubilize (Dunajski, 1980; Kanoh et al., 1988). Additional heating causes the collagen to dissolve and gelatinize (Tornberg, 2005), resulting in more tender cooked fish (Hatae et al., 1996). Moreover, collagen solubility influences the texture of cooked meat products (Eilert \& Mandigo, 1993). On the other hand, Kanoh et al. (1988) suggests that collagen is solubilized during heat treatment; however, this phenomenon might have been masked by the denaturation of myofibrillar proteins. Therefore, in this study, collagen solubilization might have contributed to a more tender texture of cooked fish after LTLT, but may not be the main cause of textural change.

Fish muscles are mainly composed of OM. Thus, the texture and flavour, i.e., palatability, can be attributed primarily to OM. However, it is unclear how the composition ratio of DM in fish muscle affects the quality of heated fish, and further studies are needed to elucidate this. The results of the present study support that LTLT heating is an excellent condition for the maintenance of the tenderness of cooked fish (Furuta et al., 2020). Therefore, high-quality fish products subjected to LTLT treatment are expected to contribute to the increase in the consumption of fish.

In conclusion, the results of protein solubility, SDS-PAGE, and DSC analysis suggest that, during heating conditions set to prevent food poisoning, the degree of actin denaturation in fish with LTLT was smaller than that under other heating conditions. In addition, the solubility of collagen tended to be higher after LTLT than after the other treatments. These results 
indicate that the different degrees of denaturation of actin and collagen may be responsible for increased tenderness texture and lower fish shrinkage with LTLT compared to treatments at higher temperatures. However, macroscopic structural changes such as contraction of myofibrils and changes in collagen fibres have not yet been elucidated and need to be studied to confirm the factors that lead to differences in the texture of fish under different heating conditions.

\section{Competing interests}

No potential conflict of interest relevant to this article was reported.

\section{Funding sources}

Yamagata Prefectural Yonezawa University of Nutrition Sciences for Strategic Research Grant (2018).

\section{Acknowledgements}

We would like to thanks Osamu Kawaguchi, Fisheries and Ocean Technologies Center, Hiroshima Prefectural Technology Research Institute, for his help in the nitrogen analysis.

\section{Availability of data and materials}

Upon reasonable request, the datasets of this study can be available from the corresponding author.

\section{Ethics approval and consent to participate}

This article does not require IRB/IACUC approval because there are no human and animal participants.

\section{ORCID}

Ayumi Furuta https://orcid.org/0000-0002-7583-1736

Yumi Hamakawa https://orcid.org/0000-0003-1348-1918

Chinami Ishibashi https://orcid.org/0000-0001-5985-1326 Ryota Mabuchi https://orcid.org/0000-0002-6911-9865

Shota Tanimoto https://orcid.org/0000-0002-0963-390X

\section{References}

Akahane T, Chihara S, Niki TP, Sano T, Tsuchiya T, Noguchi SF, et al. Differential scanning calorimetric studies on thermal behaviors of myofibrillar proteins. Nippon Suisan Gakkaishi. 1985;51:1841-6.

Bureau of Social Welfare and Public Health, Tokyo Metropolitan Government. Heating [Internet]. 2021 [cited 2021 Oct
6]. https://www.fukushihoken.metro.tokyo.jp/shokuhin/ eng/rensai/guide11.html

Daifuku M, Yaguchi Y, Nishi K, Okamoto T, Nakano H, Nishimoto S, et al. Immunostimulation effects of yellowtail heart extracts in vitro and in vivo. Biosci Biotechnol Biochem. 2011;75:638-45.

Dunajski E. Texture of fish muscle. J Texture Stud. 1980;10:301-18. Eilert SJ, Mandigo RW. Procedure for soluble collagen in thermally processed meat products. J Food Sci. 1993;58:948-9.

Fagan JD, Gormley TR. Effect of sous vide cooking, with freezing, on selected quality parameters of seven fish species in a range of sauces. Eur Food Res Technol. 2005;220:299-304.

FDA. Appendix 4: Bacterial Pathogen Growth and Inactivation [Internet]. U.S. Food \& Drug Administration. 2020 [cited 2021 Oct 6]. https://www.fda.gov/media/80390/download

FAO, WHO. Guidelines on the application of general principles of food hygiene to the control of viruses in food [Internet]. FAO. 2012 [cited 2021 Oct 6]. https://www.fao.org/input/ download/standards/13215/CXG_079e.pdf

Furuta A, Mabuchi R, Tanimoto S. Effects of different heating conditions on the texture and extracts of the meat from each part of the yellowtail Seriola quinqueradiata. Fish Sci. 2020;86:693-700.

Godiksen H, Morzel M, Hyldig G, Jessen F. Contribution of cathepsins B, L and D to muscle protein profiles correlated with texture in rainbow trout (Oncorhynchus mykiss). Food Chem. 2009;113:889-96.

Hastings RJ, Rodger GW, Park R, Matthews AD, Anderson EM. Differential scanning calorimetry of fish muscle: The effect of processing and species variation. J Food Sci. 1985;50:503-6.

Hatae K, Nakai H, Tanaka C, Shimada A, Watabe S. Taste and texture of abalone meat after extended cooking. Fish Sci. 1996;62:643-7.

Ishiwatari N, Fukuoka M, Sakai N. Effect of protein denaturation degree on texture and water state of cooked meat. J Food Eng. 2013a;117:361-9.

Ishiwatari N, Fukuoka M, Tamego A, Sakai N. Validation of the quality and microbiological risk of meat cooked with the vacuum-pack cooking method (sous-vide). Jpn J Food Eng. 2013b;14:19-28.

Kanoh S, Polo JMA, Kariya Y, Kaneko T, Watabe S, Hashimoto K. Heat-induced textural and histological changes of ordinary and dark muscles of yellowfin tuna. J Food Sci. 1988;53:673-8.

Konno K. Myosin denaturation study for the quality evalua- 
tion of fish muscle-based products. Food Sci Technol Res. 2017;23:9-21.

Laemmli UK. Cleavage of structural proteins during the assembly of the head of bacteriophage T4. Nature. 1970;227:680-5.

Liang X, Yoshida A, Osatomi K, Wang Y, Cao MJ, Hara K. Degradation of myofibrils in cultured yellowtail Seriola quinqueradiata burnt meat: effects of a myofibril-bound EDTA-sensitive protease. Fish Sci. 2012;78:147-53.

Llave Y, Shibata-Ishiwatari N, Watanabe M, Fukuoka M, Hamada-Sato N, Sakai N. Analysis of the effects of thermal protein denaturation on the quality attributes of sous-vide cooked tuna. J Food Process Preserv. 2018;42:e13347.

Niamnuy C, Devahastin S, Soponronnarit S. Quality changes of shrimp during boiling in salt solution. J Food Sci. 2007;72:S289-97.

Numakura T, Seki N, Kimura I, Toyoda K, Fujita T, Takama K, et al. Cross-linking reaction of myosin in the fish paste during setting (Suwari). Nippon Suisan Gakkaishi. 1985;51:1559-65.

Ministry of Health and Welfare, Japan. Ordinance for Enforcement of the Food Sanitation Act [Internet]. 1948 [cited 2021 Oct 6]. https://www.japaneselawtranslation.go.jp/law/ detail_main?re=01\&vm=\&id=169

Ovissipour M, Rasco B, Tang J, Sablani SS. Kinetics of quality changes in whole blue mussel (Mytilus edulis) during pasteurization. Food Res Int. 2013;53:141-8.

Qixing J, Zhengran M, Shuoshuo W, Yanshun X, Fengyu T, Xueqin X, et al. Effect of temperature on protein compositional changes of big head carp (Aristichthys nobilis) muscle and exudates. Food Sci Technol Res. 2014;20:655-61.

Samejima K, Ishioroshi M, Yasui T. Heat induced gelling properties of actomyosin: effect of tropomyosin and troponin. Agric Biol Chem. 1982;46:535-40.

Sotelo CG, Piñeiro C, Pérez-Martín RI. Denaturation of fish proteins during frozen storage: role of formaldehyde. $\mathrm{Z}$ Lebensm Unters Forsch. 1995;200:14-23.

Tornberg E. Effects of heat on meat proteins - Implications on structure and quality of meat products. Meat Sci. 2005;70:493-508.

Wattanachant S, Benjakul S, Ledward DA. Effect of heat treatment on changes in texture, structure and properties of Thai indigenous chicken muscle. Food Chem. 2005;93:337-48.

Woessner JF Jr. The determination of hydroxyproline in tissue and protein samples containing small proportions of this imino acid. Arch Biochem Biophys. 1961;93:440-7.
Woods EF. Studies on the denaturation of tropomyosin and light meromyosin. Int J Protein Res. 1969;1:29-43.

Zenitani B, Yamakita H. A modified method of the hydroxyproline determination and its content of various fish-skins and scales. Bull Fac Fish Nagasaki Univ. 1956 ;4:73-6. 